\title{
IMPLICATIONS ON RC STRUCTURE PERFORMANCE OF MODEL PARAMETER SENSITIVITY: EFFECT OF CHLORIDES
}

\author{
Rui Miguel Ferreira \\ University of Minho, School of Engineering, Department of Civil Engineering, \\ Campus de Azurém, 4800-058 Azurém, Guimarães, Portugal \\ E-mail:rmf@civil.uminho.pt
}

Received 28 May 2009; accepted 17 Jun. 2010

\begin{abstract}
This paper presents a sensitivity analysis of the parameters of the model presented in the fib - Model Code for Service Life Design for corrosion initiation due to chloride penetration. In order to adequately apply probabilistic models, a basic understanding of the model and the parameters used and the impact input values for the model parameters have on the outcome is necessary. An erroneous parameter value selection has consequences that are not always appreciated. A sensitivity analysis of the main model parameters was performed by analysing the presented model outcome. The parameter's average value was varied in a range of $20 \%$ with respect to the reference average value, whereas keeping the standard deviation constant. The results of the sensitivity analysis show that the reinforcement concrete cover and the ageing exponent of the chloride migration coefficient parameters are those that most influence the outcome of the model and therefore the durability performance of the concrete structure. The least influential model parameters, contrary to what might be expected, are $C_{c r i t}$ and $C_{\mathrm{S}, \Delta \mathrm{x}}$. Furthermore, the importance of environmental temperature on the outcome is noted. The choice of model parameter value is a critical one. Due to the uncertainty of current knowledge with regard to certain parameters caution should be exercised in the use of these models.
\end{abstract}

Keywords: durability, service-life, chlorides, parameter sensitivity, probabilistic, degradation mechanism, modeling.

\section{Introduction}

Much research work has been carried out in recent years in order to define a design approach to long-term performance of reinforced concrete structures in a marine environment (Deby et al. 2009; Baroghel-Bouny et al. 2009; Trocónis de Rincón et al. 2006, 2007; Pack et al. 2010; Kamaitis 2008, 2009; Melchers and Li 2009; Gjørv 2009; Ferreira 2010). It is commonly accepted that the dominant degradation mechanism is corrosion of the reinforcement due to the presence of chlorides. The modelling of chloride penetration is based commonly on Fick's Second Law of diffusion, adjusted to take into account certain modifications that better simulate the real phenomena, such as time dependant diffusion coefficient, varying surface chloride concentration, effects of temperature, among others (Takewaka and Mastumoto 1988; Nilsson 1994; Page 1986; Angst et al. 2009). Since model parameters for concrete durability and environmental exposure typically show a high scatter, a probabilitybased approach provides a very powerful basis for durability performance analysis (DuraCrete 2000; Gehlen and Schiessl 1999; McGee 1999; fib 2006; Deby et al. 2009; Khatri and Sirivivatnanon 2004; Kala 2008).

The design approach is based on the verification of limit states. Examples of limit states for durability are depassivation of reinforcement, cracking and spalling due to corrosion, and collapse due to cross section loss of reinforcement. With this design approach the probability of failure can be determined as a function of time. For new concrete structures, this provides an appropriate basis for establishing overall durability criteria for the structure in question (Gjørv 2003). However, for existing concrete structures, where the chloride front has still not reached the embedded steel, the approach can be used for estimating the probability of failure after a certain period of time (Ferreira et al. 2004b).

In the Model Code for Service Life Design (Bulletin 34) (fib 2006) published by fib, a design approach that is based on the verification of limit states is presented. Examples of limit states for durability are: depassivation of reinforcement, cracking and spalling due to corrosion, and collapse due to cross section loss of reinforcement. This design approach enables the determination of the probability of failure as a function of time.

In this paper, this approach to durability design of reinforced concrete structures in marine environment is analysed by a sensitivity analysis of the model parameters. Sensitivity parameters are determined. These indicate the tendency of change of the probability of failure (i.e. model outcome) as a result of change in the model parameters. For this analysis, the average values of the main model parameters are varied up to $\pm 20 \%$ and the resulting change in the probability of failure assessed. 


\section{Breif model description and implementation}

The model used for the sensitivity analysis is that which is presented in the fib Bulletin 34 for chloride-induced corrosion of reinforced concrete structures. The serviceability limit state equation for reinforcement depassivation is given by:

$$
G(X)=C_{c r i t}-C(X)>0,
$$

where $G(X)$ represents the limit state function; $X$ is the vector of model parameters, $C_{c r i t}$ is the critical chloride content at the reinforcement, and $C(X)$ is the chloride content at distance $x_{C}$ from the concrete surface after being exposed for a period of time $t$.

From the fib Bulletin 34 we obtain the model equation for determining $C(X)$ :

$$
C(X)=C_{0}+\left(C_{S, \Delta x}-C_{0}\right) \cdot\left[1-\operatorname{erf}\left(\frac{x_{C}-\Delta x}{2 \sqrt{D_{a p p, c} . t}}\right)\right]
$$

where $C_{0}$ is the initial chloride content of the concrete mix (weight - \%/cement); $C_{s, \Delta x}$, is the surface chloride content (weight - \%/cement) at a depth of $\Delta x(\mathrm{~m})$ from the concrete surface; erf is the error function; $x_{C}$ is the concrete cover $(\mathrm{m}) ; \Delta x$ is the depth of the convection zone $(\mathrm{m}) ; D_{a p p, C}$ is the apparent coefficient of chloride diffusion through concrete $\left(\mathrm{m}^{2} / \mathrm{s}\right)$, and $t$ is time $(\mathrm{s})$.

The apparent coefficient of chloride diffusion of concrete can be determined by means of the following equation

$$
D_{a p p, c}=k_{e} D_{R C M, 0}\left(\frac{t_{0}}{t}\right)^{a},
$$

where $D_{R C M, 0}$ is the chloride migration coefficient $\left(\mathrm{m}^{2} / \mathrm{s}\right)$; $t_{0}$ is the reference point of time $(\mathrm{s}) ; a$ is the ageing exponent $(-)$, and $k e$ is the environmental transfer variable (-) given by

$$
k_{e}=\exp \left(b_{e}\left(\frac{1}{T_{r e f}}-\frac{1}{T}\right)\right)
$$

where $b e$ is a regression variable; $T_{r e f}$ is the standard test temperature, $293(\mathrm{~K})$ and $T$ is the temperature of the ambient air or the structural element $(\mathrm{K})$.

The probabilistic design method is implemented with the Monte Carlo simulation method (Ferreira and Jalali 2006; Ferreira 2009). The main requirement is that all the model parameters be described by a probability density function (PDF). The Monte Carlo simulation involves sampling at random from the model parameters' PDF to simulate artificially a large number of input data, and then to evaluate the outcome of model simulation. The probability of failure, i.e. reinforcement depassivation, is calculated based on the evaluation of the limit state function for a large number of trials.

In this case, each model parameter $X i$ is randomly sampled from the parameters' PDF to generate the sample value using the inverse transform method (Enevold- sen and Sørensen 2000). The limit state function $G\left(x^{\prime}\right)=$ 0 is then assessed, and if violated, i.e. $G\left(x^{\prime}\right)<0$, the structure has failed from a durability point of view. The simulation is repeated many times, each time with a randomly chosen vector $\left[x^{\prime}\right]$ of $x^{\prime}$ values. For the Monte Carlo simulation the probability of failure of the limit state equation is given by

$$
p_{f}=\frac{1}{N} \sum_{j=1}^{N} I\left[G\left(x_{j}^{\prime}\right) \leq 0\right],
$$

where $I[x]$ is the indicator function $(I=1$ if $[x]$ is true; $I=0$ if $[x]$ is otherwise) and $N$ is the number of trials. $I$ [ ] indicates that only values of $G\left(x^{\prime}\right) \leq 0$ contribute to the probability of failure. The accuracy of the simulation will increase as the number of trials undertaken, $N$, increases.

The reliability index, $\beta$, can be calculated from the probability of failure by using the inverse of the standard normal distribution function, $(\Phi)$, assuming that $G(X)$ is a normally random variable based on the Central Limit Theorem.

$$
\beta=-\Phi^{-1}\left(p_{f}\right)
$$

\section{Parameter sensitivity analysis}

The sensitivity analysis of the model parameters was performed for three case studies. The first case study is based partially on the requirements presented in the EN 1992-1 and the EN 206-1 (CEN 2004, 2007). The second case study is a wharf structure located in the Trondheim fjord (Norway), built for a service life of 50 years, produced with CEM I type cement concrete with silica fume additions (Gjørv 2003; Ferreira et al. 2004a). The third case study is a bridge over the Tagus River (Portugal) built for a service life of 120 years with CEM I type cement concrete with fly ash additions (Taborda 1998).

The values for the model parameters $C_{c r i t}, \Delta \mathrm{x}, b e$, and $a$ are based on those presented in the fib Bulletin 34. The environmental parameters $C_{s}, \Delta x$ and $T$, and the parameters that define the quality of the concrete structure, $x_{C}$ and $D_{R C M, 0}$, are based on design assumptions and measurements performed on the structures (CEN 2004, 2007; Gjørv 2003; Ferreira et al. 2004a; Taborda 1998).

Table 1 presents the data necessary to characterize the model parameters used - namely the distribution type, the average and the standard deviation of each parameter.

The minimum and maximum limits for the parameters with beta distributions appear between square brackets. The initial chloride content is considered to be zero. The outcome of the simulation is dependent on the correct choice of PDF to represent the parameter and on the sensitivity to a change of the PDF parameters (e.g.: average and standard deviation). The PDF should fit the available parameter data accordingly, not only in the neighborhood of the average value, but in some cases also in the distribution tails. The PDF of the parameter should take into account the physical limitation of the parameter. 
Table 1. Characterization of the stochastic parameters used in the model ( $\mu$-average, $\sigma-$ standard deviation)

\begin{tabular}{l|l|c|c|c|c|c|c}
\hline \multirow{2}{*}{ Parameter } & \multirow{2}{*}{ Distribution Type } & \multicolumn{2}{c|}{ Case I } & \multicolumn{2}{c}{ Case II } & \multicolumn{2}{c}{ Case III } \\
\cline { 3 - 8 } & & $\mu$ & $\sigma$ & $\mu$ & $\sigma$ & $\mu$ & $\sigma$ \\
\hline $\mathrm{C}_{\mathrm{crit}}(\mathrm{wt}-\% / \mathrm{cem})$ & Beta [0.2; 1.0] & 0.60 & 0.10 & 0.60 & 0.15 & 0.60 & 0.15 \\
\hline $\mathrm{C}_{\mathrm{s}, \Delta \mathrm{x}}(\mathrm{wt}-\% / \mathrm{cem})$ & Normal & 3.38 & 0.34 & 2.75 & 0.28 & 3.38 & 0.34 \\
\hline $\mathrm{x}_{\mathrm{C}}(\mathrm{mm})$ & Normal & 60.0 & 8.0 & 57.4 & 4.2 & 80.0 & 8.0 \\
\hline$\Delta \mathrm{x}(\mathrm{mm})$ & Beta [6.0; 11.0$]$ & 8.9 & 5.6 & 8.9 & 5.6 & 8.9 & 5.6 \\
\hline $\mathrm{D}_{\mathrm{RCM}, 0}\left(\mathrm{e}-12 . \mathrm{m}^{2} / \mathrm{s}\right)$ & Normal & 2.00 & 0.40 & 1.91 & 0.43 & 2.00 & 0.40 \\
\hline $\mathrm{b}_{\mathrm{e}}(-)$ & Normal & 4800 & 200 & 4800 & 200 & 4800 & 200 \\
\hline $\mathrm{T}_{\text {real }}\left({ }^{\circ} \mathrm{C}\right)$ & Normal & 20.0 & 1.0 & 15.0 & 1.0 & 20.0 & 1.0 \\
\hline $\mathrm{a}(-)$ & Beta [0.0; 1.0$]$ & 0.3 & 0.12 & 0.39 & 0.05 & 0.60 & 0.15 \\
\hline $\mathrm{t}_{\mathrm{SL}}($ years $)$ & Deterministic & & 50 & & 50 & & 120 \\
\hline
\end{tabular}

The sensitivity analysis is performed considering the effect of change on the model outcome as a result of change of the average input value of a stochastic model parameter. A change of the model parameter will influence the limit state function and the probability of failure associated with it. The sensitivity parameter $\varphi$ that quantifies this relationship can be determined according to the following expression

$$
\varphi=\frac{\left.p_{f}\right|_{x_{i}+\Delta x_{i}}-\left.p_{f}\right|_{x_{i}}}{\Delta x_{i}},
$$

where $X i$ is the parameter of interest; $\Delta X_{i}$ is a small change in the parameter and $p_{f} \mid X_{i}$ and $p_{f} \mid X_{i}+\Delta X_{i}$ are the respective probabilities of failure. The sensitivity parameter indicates the tendency of change of the probability of failure (i.e. model outcome) as a result of change in the model parameters.

The outcome of the sensitivity parameter will depend on whether the design solution for any given structure is more or less optimized. As a result, optimized designs are expected to have smaller variations where as un-optimized designs are expected to have large variations. The amplitudes of these variations make direct comparison of the results for different structures difficult. Therefore, it is necessary to normalize the results converting the amplitude of the variation to a limited scale. To normalize it is necessary to divide all the sensitivity parameters for a specific case study by the maximum absolute value obtained for that case study. The normalized sensitivity parameter $\varphi *$ obtained is given by

$$
\varphi^{*}=\frac{\varphi}{\varphi_{M A X}} .
$$

With this transformation, the $\varphi *$ closer to $|1|$ are the more influential parameters, whereas the $\varphi *$ closer to 0 are the lesser influential parameters.

For the sensitivity analysis, the average values of the main model parameters ( $\Delta x$ and be are excluded) are varied according to the following limits: $\pm 5 \%, \pm 10 \%$ and $\pm 20 \%$.

\section{Analysis results}

Three case studies are evaluated to assess the sensitivity of the model parameters. Considering the limit state function in Eq. (1) and the data given in Table 1 for parameter characterization, 178,000 samples direct Monte Carlo simulation resulted in the sensitivity parameters presented in Figs. 1, 2 and 3.

Care should be taken in the interpretation of the obtained results. For the parameters $C_{S}, \Delta x, x_{C}, D_{R C M, O}$ and $T_{\text {real }}$ positive and negative changes can occur naturally on the concrete structure due to intrinsic variability associated with these parameter as result of, for example, heterogeneous properties or the influence of workmanship. On the other hand, the parameters $C_{c r i t}$ and $a$ represent certain material characteristics influenced by, among other things, cement type and content. Therefore, changes of these parameters often result from changes in type of concrete composition and therefore do not occur naturally on the same structure (e.g.: an age exponent of 0.3 and 0.6 represent two distinct concretes types with different characteristics).

Experienced engineers know how parameter value changes might influence the model outcome, but to what extent is usually not known.

From Figs. 1-3 it can be seen that in general the positive and negative variation of the sensitivity parameter are approximately the same. This is due to the fact that the design considerations are more or less optimised, and that the variation of the parameter is performed within restricted limits. The slight differences observed can be attributed to the number of trials performed for each simulation. However, an exception is observed in case studies 2 and 3 for the model parameters $x_{C}$ and $a$. As these are optimised designs, positive changes do not improved the performance of the structure (probability of failure) significantly. However, negative change influence adversely the performance of the structure and the probability of failure increases accordingly.

From Figs. 1-3 if can be seen that the tendency of change of the parameter is the same irrespective of the case study. For example, an increase in the $C_{c r i t}$ reduces 


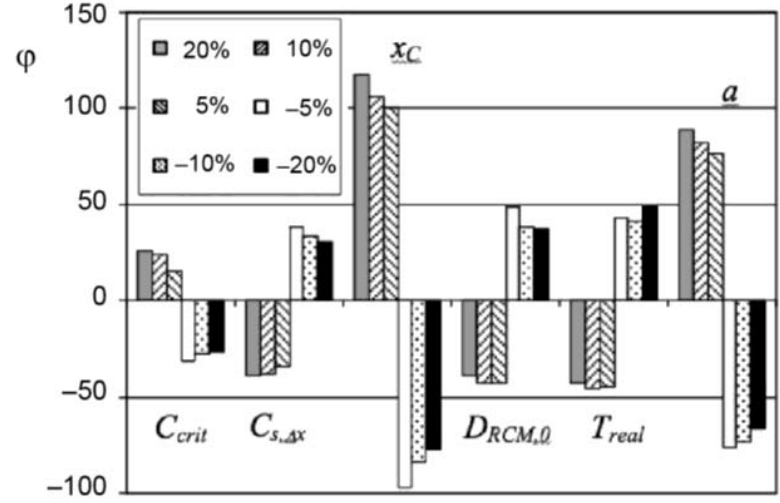

Fig. 1. Sensitivity parameters for Case study I

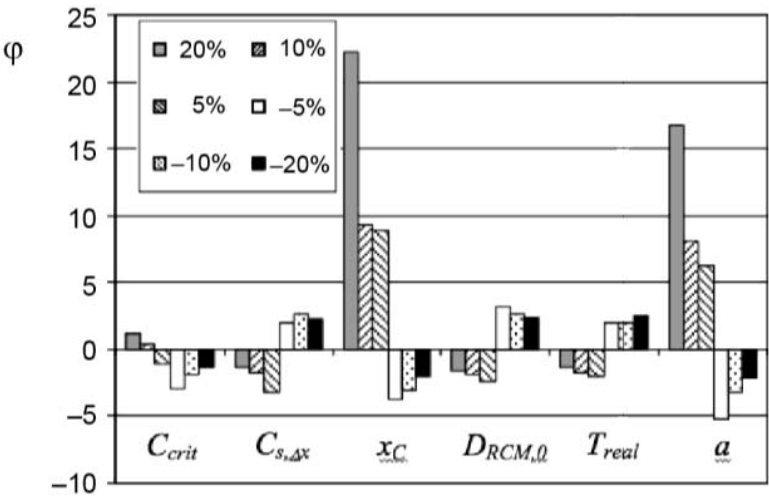

Fig. 2. Sensitivity parameters for Case study II

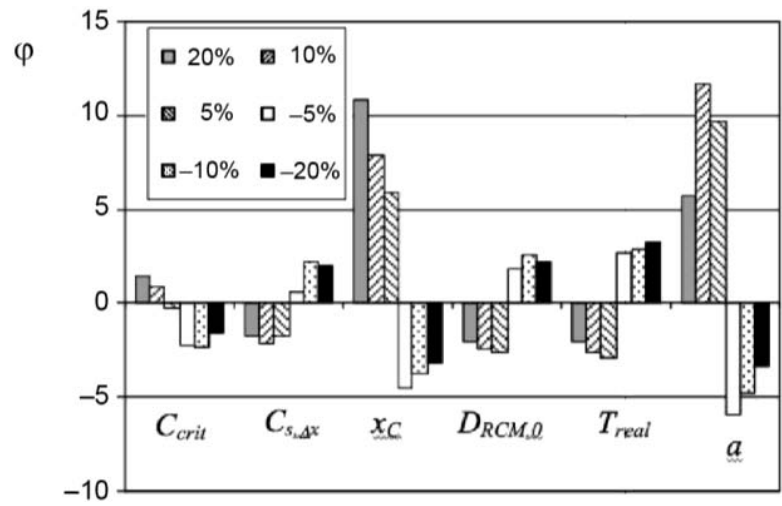

Fig. 3. Sensitivity parameters for Case study III

the probability of failure, and vice versa. Table 2 summarises the tendency of change of the probability of failure as a result of an increase in the model parameters.

Table 2. Influence of an increase in model parameters on the probability of failure

\begin{tabular}{c|l}
\hline Variable & Tendency \\
\hline$C_{c r i t}$ & Decrease of the pf \\
$C_{s, \Delta x}$ & Increase of the pf \\
$x_{C}$ & Decrease of the pf \\
$D_{R C M, 0}$ & Increase of the pf \\
$T_{\text {real }}$ & Increase of the pf \\
$a$ & Decrease of the pf \\
\hline
\end{tabular}

For case study I, the sensitivity parameters exceed values of $100 \%$ indicating that the probability of failure more than doubles when changes of $5 \%$ or greater in the model parameter are implemented. This occurs for $x_{C}$. The values of the sensitivity parameters for case study I are much larger than those of case study II or case study III. This is due to the fact that the design considerations are further away from optimised values, i.e., the model parameters chosen can be improved to enhance durability performance. The parameters $x_{C}$ and $a$ have the greatest influence (more than double than that of the other parameters), and $C s$ and $C_{c r i t}$ have the least.

In case study II, the sensitivity parameters are almost all less than $10 \%$ except for $-20 \% x_{C}$ and $-20 \% a$. The reason has been commented previously.

As in case study I, the influence of change in the model parameter on probability of failure is identical for case study II and III.

It is possible to analyse each case individually with regard to the sensitivity parameter. However, when comparing different cases this is difficult due to the scale difference of the sensitivity parameter of each case. Therefore, using Eq. (8), the sensitivity parameters are converted into normalised sensitivity parameters varying from -1.0 (indicating a positive influence on the outcome - i.e. a decrease in the probability of failure) to +1.0 (indicating a negative influence on the outcome - i.e. an increase in the probability of failure).

In Table 3, the average normalized sensitivity parameter $\varphi *$ for positive and negative variations of each model parameter is presented.

Table 3. Normalised sensitivity parameter $\varphi *$ for the three case studies

\begin{tabular}{c|rr|rr|rr}
\hline \multirow{2}{*}{ Var. } & \multicolumn{2}{|c|}{ Case I } & \multicolumn{2}{c|}{ Case II } & \multicolumn{2}{c}{ Case III } \\
& \multicolumn{1}{|c}{$+\%$} & $-\%$ & \multicolumn{1}{c}{$+\%$} & \multicolumn{1}{c}{$-\%$} & \multicolumn{1}{c}{$+\%$} & \multicolumn{1}{c}{$-\%$} \\
\hline$C_{\text {crit }}$ & -0.2 & 0.2 & -0.1 & 0.0 & -0.2 & 0.1 \\
$C_{S, \Delta x}$ & 0.3 & -0.3 & 0.1 & -0.1 & 0.1 & -0.2 \\
$x_{C}$ & -0.7 & 0.9 & -0.1 & 0.6 & -0.3 & 0.7 \\
$D_{R C M, 0}$ & 0.4 & -0.4 & 0.1 & -0.1 & 0.2 & -0.2 \\
$T_{\text {real }}$ & 0.4 & -0.4 & 0.1 & -0.1 & 0.3 & -0.2 \\
$a$ & -0.6 & 0.7 & -0.2 & 0.6 & -0.4 & 0.8 \\
\hline
\end{tabular}

Considering $\varphi^{*}>|0.7|$ as very sensitive and $\varphi *<|0.2|$ hardly sensitive the normalized parameters can be classified into the following groups:

- very sensitive (large influence on the pf): $x_{C}$ and $a$;

- moderately sensitive (average influence on the pf): $D_{R C M, 0}$ and $T_{\text {real }}$;

- slightly sensitive (little influence on the pf): $C_{c r i t}$ and $C_{S, \Delta x}$.

To observe that $x_{C}$ and $a$ have a significant effect on the outcome is known, but to observe that $D_{R C M, 0}$ is not as influential and that $T_{\text {real }}$ is as influential as $D_{R C M, 0}$ is unexpected. However, what is surprising is to observe that $C_{c r i t}$ and $C_{S, \Delta x}$ are the least influential parameters. 
This is of relevance because often it is stated that the precise definition of $C_{c r i t}$ is crucial to the outcome of the durability performance assessment. With this analysis, it seem that the contribution of $C_{c r i t}$ is small.

\section{Conclusions}

The analysis of the sensitivity parameters for the three case studies has resulted in some interesting conclusions. The importance of each model parameter on the model outcome is better understood. The most influential model parameters are $x_{C}$ and $a$. The least influential model parameters, contrary to what is expected, are $C_{c r i t}$ and $C_{S, \Delta x}$. Furthermore, the influence temperature has on the outcome is considered to be significant, and unexpected.

The sensitivity analysis can help engineers to better understand the influence of the model parameters on the outcome, and therefore more care has to be taken in choosing the appropriate value.

Probabilistic modelling due to their very nature can be manipulated to conform to specific requirement by model parameter manipulation. Therefore, it is necessary to establish for each model what are the accepted distribution types and what are the valid limits for parameter variation (limits of average values and standard deviations). In this way, the misuse of probabilistic modelling should be minimised.

\section{Acknowledgments}

This work was developed as part of the research project SELICON - Service Life Design - Modelling the durability performance of Concrete (PTDC/ECM/69565/ 2006), funded by the Foundation for Science and Technology, of the Ministry of Science, Technology and Higher Education of Portugal.

\section{References}

Angst, U.; Elsener, B.; Larsen, C. K.; Vennesland, Ø. 2009. Critical chloride content in reinforced concrete - A review, Cement and Concrete Research 39(12): 11221138. doi:10.1016/j.cemconres.2009.08.006

Baroghel-Bouny, V.; Nguyen, T. Q.; Dangla, P. 2009. Assessment and prediction of RC structure service life by means of durability indicators and physical/chemical models, Cement and Concrete Composites 31(8): 522-534. doi:10.1016/j.cemconcomp.2009.01.009

CEN-EN 1992-1-1. 2004. Eurocode 2. Design of concrete structures. Part 1: General rules and rules for buildings. CEN, Brussels.

CEN-EN 206-1. 2007. Concrete. Part 1: Specification, performance, production and conformity. CEN, Brussels.

Deby, F.; Carcassès, M.; Sellier, A. 2009. Probabilistic approach for durability design of reinforced concrete in marine environment, Cement and Concrete Research 39: 466471. doi:10.1016/j.cemconres.2009.03.003

DuraCrete. 2000. General Guidelines for Durability Design and Redesign. The European Union - Brite EuRam III, Project No. BE95-1347: Probabilistic Performance Based Durability Design of Concrete Structures. Document R 15.

Enevoldsen, I.; Sørensen, J. D. 2000. Course on Statistical Analysis. University of Aalborg, Denmark.
Ferreira, R. M. 2010. Optimization of RC structure performance in marine environment, Engineering Structures 32(5): 1489-1494. doi:10.1016/j.engstruct.2010.02.011

Ferreira, R. M. 2009. Service-life design of concrete structures in marine environments. Verlag-DM Publishing. Germany.

Ferreira, R. M.; Jalali, S.; Årskog, V.; Gjørv, O. E. 2004a. Probability-based Durability Analysis of Concrete Harbour Structures, in 4th International Conference on Concrete under Severe Conditions (CONSEC 04): Environment and Loading, Seoul, Korea, June 2 - July 1, 2004, 999-1006.

Ferreira, R. M.; Liu, G.; Nilsson, L.; Gjørv, O. E. 2004b. Blastfurnace slag cements for concrete durability in marine environment, in 4th International Conference on Concrete under Severe Conditions (CONSEC 04): Environment and Loading, Seoul, Korea, June 27 - July 1, 2004, 109-116.

Ferreira, R. M.; Jalali, S. 2006. Software for probability based durability analysis of concrete structures, in Proceedings of International Conference on Concrete Repair, Rehabilitation and Retrofitting ICCRRR, Cape Town, South Africa, 321-326.

fib Bulletin. 2006. No. 34. Model Code for Service Life Design.

Gehlen, C.; Schiessl, P. 1999. Probability-Based Durability Design for the Western Scheldt Tunnel, Structural Concrete 2 : $1-7$.

Gjørv, O. E. 2003. Durability design and construction quality of concrete structures, in, 4th International Conference on Concrete under Severe Conditions (CONSEC 04): Environment and Loading, Seoul, Korea, June 27-July 1, 2004, 309-320.

Gjørv, O. E. 2009. Durability Design of Concrete Structures in the Severe Environments. Taylor \& Francis.

Kala, Z. 2008. Fuzzy probability analysis of the fatigue resistance of steel structural members under bending, Journal of Civil Engineering and Management 14(1): 67-72. doi:10.3846/1392-3730.2008.14.67-72

Kamaitis, Z. 2008. Modelling of corrosion protection for reinforced concrete structures with surface coatings, Journal of Civil Engineering and Management 14(4): 241-249. doi:10.3846/1392-3730.2008.14.23

Kamaitis, Z. 2009. Modelling of corrosion protection as standby system for coated reinforced concrete structures, Journal of Civil Engineering and Management 15(4): 387-394. doi:10.3846/1392-3730.2009.15.387-394

Khatri, R. P.; Sirivivatnanon, V. 2004. Characteristic service life for concrete exposed to marine environments, Cement and Concrete Research 34(5): 745-752. doi:10.1016/S0008-8846(03)00086-3

McGee, R. 1999. Modelling of Durability Performance of Tasmanian Bridges, in Proceedings of the 8th Int. Conference on the Application of Statistics and Probability. Sydney, Australia.

Melchers, R. E.; Li, C. Q. 2009. Reinforcement corrosion initiation and activation times in concrete structures exposed to severe marine environments, Cement and Concrete Research 39(11): 1068-1076. doi:10.1016/j.cemconres.2009.07.003

Nilsson, L. O.; Massat, M.; Tang, L. 1994. The effect of nonlinear chloride binding on the prediction of chloride penetration into concrete structures, in 3rd International Conference on Durability of Concrete, Nice, France. ACI SP-145: 469-486.

Pack, S.; Jung, M.; Song, H.; Kim, S.; Ann, S. 2010. Prediction of time dependent chloride transport in concrete structures 
exposed to a marine environment, Cement and Concrete Research 40(2): 302-312.

doi:10.1016/j.cemconres.2009.09.023

Page, C. L.; Short, N. R.; Holdon, W. R. 1986. Materials Research Group. The influence of different cements on chloride-induced corrosion of reinforcing steel, Cement and Concrete Research 16(1): 79-86. doi:10.1016/0008-8846(86)90071-2

Taborda, J. 1998. Bridge Vasco da Gama high performance concrete, in Proceeding of ERMCO98, Lisbon, Portugal. 2: 723-735.

Takewaka, K.; Mastumoto, S. 1988. Quality and Cover Thickness of Concrete based on the Estimation of Chloride Penetration in Marine Environments, ACI SP 109-17, American Concrete Institute, 381-400.

Trocónis de Rincón, O.; Duracon Collaboration. 2006. Durability of concrete structures: DURACON, an iberoamerican project. Preliminary results, Building and Environment 41(7): 952-962. doi:10.1016/j.buildenv.2005.04.005

Trocónis de Rincón, O.; Sánchez, M.; Millano, V.; Fernández, R.; de Partidas, E. A.; Andrade, C.; Martínez, I.; Castellote, M.; Barboza, M.; Irassar, F.; Montenegro, J. C.; Vera, R.; Carvajal, A. M.; de Gutiérrez, R. M.; Maldonado, J.; Guerrero, C.; Saborio-Leiva, E.; Villalobos, A. C.; Tres-Calvo, G.; Torres-Acosta, A.; Pérez-Quiroz, J.; Martínez-Madrid, M.; Almeraya-Calderón, F.; CastroBorges, P.; Moreno, E. I.; Pérez-López, T.; Salta, M.; de Melo, A. P.; Rodríguez, G.; Pedrón, M.; Derrégibus, M. 2007. Effect of the marine environment on reinforced concrete durability in Iberoamerican countries: DURACON project/CYTED, Corrosion Science 49(7): 2832-2843. doi:10.1016/j.corsci.2007.02.009

\section{MODELIO PARAMETRŲ JAUTRUMO POVEIKIS RC STRUKTŪRAI}

\section{R. M. Ferreira}

\section{Santrauka}

Straipsnyje pristatoma sukurta modelio parametru jautrumo analizė - modelio sistema projektuoja korozijos, atsirandančios dèl chlorido skvarbos, atsiradimo tikimybę. Siekiant tinkamai taikyti tikimybinius modelius būtinas bazinis supratimas apie modelyje naudotų parametrų ir ịvesties reikšmių parametrų poveikio rezultatus. Klaidingas parametro reikšmės pasirinkimas gali lemti netinkamą įvertinimą. Pagrindinių modelio parametrų jautrumo analizè buvo atlikta tiriant pateikto pavyzdžio rezultatus. Vidutinė parametro vertė buvo varijuojama $20 \%$ atsižvelgiant į vidutinę atskaitos vertę ir išlaikant standartinio nuokrypio konstantą. Jautrumo analizès rezultatai rodo, kad armuotos betoninès dangos ir chlorido migracijos koeficiento senejimo rodiklio parametrai yra tie, kurie gali labiausiai paveikti modelio rezultatus ir betono struktūros patvarumo charakteristikas. Mažiau įtakingi modelio parametrai, priešingai nei būtų galima tikètis, yra $C_{c r i t}$ ir $C_{S, \Delta x}$. Aprašyta aplinkos temperatūros įtaka rezultatams. Pasirinkti modelio parametrų vertes yra labai svarbu. Dėl dabartinių žinių apie tam tikrụ parametrụ neapibrèžtumą reikia būti atsargiems taikant šiuos modelius.

Reikšminiai žodžiai: ilgaamžiškumas, chloridai, parametrų jautrumas, tikimybinė analizè, degradacijos mechanizmas, modeliavimas.

Rui Miguel FERREIRA. An Assistant Professor of the Department of Civil Engineering in the School of Engineering at the University of Minho, Portugal. He is a member of RILEM TC Committees 213 (Model assisted integral service life prediction of steel reinforced concrete structures with respect to corrosion induced damage) and 230 (Performance-based specifications and control of concrete durability). His research interests include service life design, degradation mechanism of reinforced concrete structures, NDT and effect of additions on concrete performance. 